Santa Clara University

Scholar Commons

Economics

Leavey School of Business

3-16-2016

\title{
Inequality of Happiness: Evidence of the Compression of the Subjective-Well-Being Distribution with Economic Growth
}

John Ifcher

Santa Clara University, jifcher@scu.edu

Homa Zarghamee

Follow this and additional works at: https://scholarcommons.scu.edu/econ

Part of the Economics Commons

\section{Recommended Citation}

Ifcher, J., \& Zarghamee, H. (2016). Inequality of Happiness: Evidence of the Compression of the Subjective-Wellbeing Distribution with Economic Growth. In K. Basu \& J. E. Stiglitz (Eds.), Inequality and Growth: Patterns and Policy (pp. 225-249). Palgrave Macmillan UK.

Reproduced with permission of Palgrave Macmillan. This extract is taken from the author's original manuscript and has not been edited. The definitive, published, version of record is available here: http://doi.org/10.1057/9781137554543_8

This Book Chapter is brought to you for free and open access by the Leavey School of Business at Scholar Commons. It has been accepted for inclusion in Economics by an authorized administrator of Scholar Commons. For more information, please contact rscroggin@scu.edu. 
Economics Department

Subjective-Well-Being Inequality and Per Capita Income:

Evidence from the World Values

John Ifcher and Homa Zarghamee

Working Paper No. 2014-04-SCU-ECON

http://www.scu.edu/business/economics/wpscue

(C) 2014 by John Ifcher, and Homa Zarghamee. All rights reserved. Permission to quote or cite material within without express, written assent is limited to no more than two paragraphs with full attribution. Views expressed by the authors are not necessarily those of Santa Clara University or the Leavey School of Business. 


\title{
Subjective-Well-Being Inequality and Per Capita Income: Evidence from the World Values Surveys
}

\author{
John Ifcher
}

Homa Zarghamee

\begin{abstract}
The field of "Happiness Research" has grown markedly. A central question is whether higher income and/or economic growth rates are associated with higher levels of Subjective Well Being (SWB). Crosssectional analysis clearly indicates that there is a positive relationship between income and SWB. However, in time series this relationship may vanish (the Easterlin Paradox). In this paper, we examine the relationship between income, economic growth, and SWB inequality using data from the World Values Survey and World Development Indicators. The results indicate that per capita income is inversely related to SWB inequality in cross-sectional analysis. There is also evidence that greater economic growth is associated with a greaterdecrease in SWB inequality. The relationship between income, economic growth, and SWB inequality is not explained by income inequality.
\end{abstract}




\section{Introduction}

The use of Subjective Well-Being (SWB) measures in economics research has grown markedly (Kahneman and Krueger 2006). This has come about for at least two reasons. First, the measures have been systematically validated as reliable for examining a range of questions. Second, economists have long relied on income as a proxy for well-being. However, research shows that there are potentially large slippages between economic indicators and well-being (Diener and Seligman 2004). Thus, SWB measures have become an important alternative proxy for well-being. Indeed, SWB measures have also caught the attention of policy makers. The OECD launched the Better Life Index in 2011 as an alternative well-being measure; and former French President, Nicolas Sarkozy, formed the Stiglitz Commission in 2008 to identify the limits of Gross Domestic Product (GDP) as a measure of well-being and to identify alternative measures (Stiglitz, Sen, and Fitoussi 2010).

When studying the distribution of income, economists have long recognized the importance of examining measures of central tendency and dispersion, as the latter are necessary to understand income inequality and poverty (Stiglitz, Sen, and Fitoussi 2010). Thus, there is a vast literature analyzing both the first and second moments of the distribution of income. For example, the Lorenz and Kuznets curves try to model the distribution of income, and the Gini coefficient summarizes the entire distribution in a scalar (see Atkinson 1970; Gastwirth 1972; Gini 1921; Gottschalk and Smeeding 1887; Kuznets 1955; and Lorenz 1905). In contrast, the vast majority of SWB research focuses on mean SWB. Given the current interest in SWB measures, and recognizing that the entire distribution of SWB merits study, we believe it is important to study SWB inequality (dispersion) as well as mean SWB.

In this paper, we contribute to the emerging SWB literature by investigating the relationship between economic growth and SWB inequality using data from the World Values Survey (WVS) and the World Bank's World Development Indicators (WDI). The results suggest that economic growth is inversely related to SWB inequality in cross-sectional analysis. There is also some evidence from time-series analysis that countries that experience greater economic growth rates also experience the greater decreases in SWB inequality, although this pattern does not hold for two of the fastest growing countries in the dataset. This is important because it indicates that economic growth may reduce SWB inequality over time, even if it does not increase mean SWB. The paper proceeds as follows. Section II reviews the related literature. Section III describes the data. Section IV presents the results. Section V concludes.

\section{Literature review}

The vastness of the income inequality literature illustrates the importance of studying income's distribution (for example, Atkinson 1970; Gastwirth 1972; Gini 1921; Gottschalk and Smeeding 
1997; Lorenz 1905). In contrast, there are only a few papers that have studied SWB inequality. ${ }^{1}$ Stevenson and Wolfers (2008b) examine trends in happiness inequality in the United States from 1972 to 2006 using the General Social Survey. They find that happiness inequality decreased during this period. The authors juxtapose their finding with the concurrent rise in income inequality in the United States but do not examine the relationship between happiness inequality and economic growth.

Easterlin (2012) studies SWB inequality in developed capitalist countries and in countries that transitioned from socialism to capitalism using the WVS. He finds that developed capitalist countries (with the exception of Nordic welfare states) had greater SWB inequality than "soviet style" socialist countries before the transition. This pattern reverses after the transition, with the increase in SWB inequality in former socialist countries resulting from decreased SWB among low-income individuals. Easterlin et al. (2012) find the same pattern in China after the restructuring of state-owned enterprises (SOEs) and trimming of social safety nets.

Finally, Veenhoven (2005a) attempts to refute the "The Great U-Turn:” the return of social inequality in modern society. ${ }^{2}$ Veenhoven examines trends in SWB inequality using the standard deviation of life satisfaction between 1973 and 2001 in Eurobarometer data. He shows that in that time period SWB inequality decreased. In his analysis, Veenhoven does not examine the relationship between SWB inequality and economic growth. He does, however, examine the relationships between SWB inequality and modernity using data from the WVS. To do so, he plots SWB inequality against several measures of modernity, such as purchasing power, freedom in private life, urbanization, and education. He concludes that as countries "modernize," SWB inequality decreases. His analysis, however, is limited to a cross-sectional analysis using only two waves of data from the WVS. Our paper builds upon Veenhoven's (2005a) paper in two important ways. First, we use all five waves of the WVS, and second, we compare SWB inequality and per-capita GDP (GPDpc) using both cross-sectional and time-series analysis. This is important since, as discussed below, many researchers believe that the relationship between mean SWB and GDPpc is different in cross-section than in time-series.

Cross-sectional analysis indicates that there is a positive relationship between mean SWB and GDPpc within a country and also across countries (Easterlin 1974; Stevenson and Wolfers 2008a; and Stevenson and Wolfers 2013). That is, within a country, individuals with higher income have higher SWB, on average, than individuals with lower income; and countries with higher average income have higher mean SWB. However, many researchers believe that this relationship vanishes in time-series; this is the "Easterlin Paradox," introduced in Easterlin

\footnotetext{
${ }^{1}$ Clark, Fleche, and Senik (2012) was developed simultaneously and independently from this paper, on the same topic.

${ }^{2}$ This article was published in a special issue of the Journal of Happiness Studies (volume 6, number 4), which includes four papers that focus on happiness inequality (Veenhoven 2005a; Kalmijn and Veenhoven 2005; Veenhoven and Kalmihn 2005; and Ott 2005). Veenhoven (2005b) introduces the series. The other three papers are more pertinent to methodology, one of which we cite in the data section.
} 
(1974) (see also Easterlin 1995; Easterlin 2013; and Easterlin et al. 2010). Various explanations have been proposed for the divergent results, for example, that relative income, not absolute income, is associated with SWB, or that individuals adapt to higher income over time. After the publication of the Easterlin Paradox, a heated debate has developed regarding the validity of Easterlin's finding, as many find it hard to believe that mean SWB does not increase with per capita income within a country over time. To determine if the paradox exists, the important variable to consider appears to be the time frame of the analysis. When Easterlin first proposed the paradox, he found that in long-term time series, the correlation between mean happiness and per capita income disappeared. A thorough critique of the paradox is by Stevenson and Wolfers (2008a), who examine multiple shorter time series to demonstrate that the association between mean happiness and per capita income does exist. The main difference between these two analyses is that Stevenson and Wolfers consider shorter time series and Easterlin considers longer time series. It is important to note that the existence of the Easterlin Paradox is a subject of active debate (for example, Stevenson and Wolfers 2008a; Stevenson and Wolfers 2013; and Easterlin et al. 2010). For the purpose of this paper, we can remain agnostic.

We contribute to the SWB inequality literature by performing a systematic analysis of the relationship between SWB inequality and economic growth. We examine the relationship between SWB inequality and economic growth in both a cross-sectional and time-series analysis. Because our results are for the most part consistent across these two analyses, they do not present the challenge that the Easterlin paradox does. Our research also suggests that, despite the controversy the Easterlin paradox presents, there may be an additional benefit from increasing per capita income within a country: namely, decreasing SWB inequality.

\section{Data}

The SWB data for this study comes from the WVS, the most comprehensive dataset, in terms of years and countries covered, available for studying SWB. It has been administered five times. The first wave, administered between 1981 and 1984, includes 21 countries and the fifth wave, administered between 2005 and 2008, includes 56 countries. In total, there are over 350,000 respondents; the survey has been administered in 98 countries at least once; and there are 248 country-wave pairs (for example, the United States - Wave 1).

The WVS includes a standard Life-Satisfaction (LS) question as well as a happiness question. The former asks: "All things considered, how satisfied are you with your life as a whole these days?” where " 1 ” is defined as “dissatisfied” and “10” is defined as "satisfied;" Figure 1a presents a histogram of the LS data. Like Veenhoven's study, our analysis uses the standard deviation of the LS question rather than the happiness question. Its response scale is larger (10 possible responses versus 4 ) and the standard deviation is greater than is the standard deviation of happiness (2.45 versus 0.74). Further, the LS question is believed to be better for making cross-country comparisons than the happiness question (Di Tella et al 2001). Of the 248 country-wave pairs in the WVS, there is LS data for 246; LS data is missing for Korea 1996 and 
Pakistan 1997. Also, Indian LS data is considered invalid and is dropped, as the response scale changed between waves (Easterlin and Sawangfa 2010). This leaves 242 country-wave pairs.

The unit of analysis throughout the study is the country-wave pair. For each country-wave pair, we calculate the mean and Standard Deviation of LS ( $\left.\mathrm{SD}_{\mathrm{LS}}\right)$. The latter is our measure of SWB inequality. ${ }^{3}$ Figure $1 \mathrm{~b}$ presents a histogram of the standard deviation of LS by country-wave pair. For each country-wave pair, we also calculate the percentage of respondents who are female, married, not parents, unemployed, and did not complete high school as well as the mean age.

The GDPpc data comes from the World Bank’s WDI. All GDPpc figures are in 2000 U.S. dollars. Of the 242 country-wave pairs in the analysis, there is GDPpc data for 237. GDPpc data is missing for Northern Ireland 1981, 1990, \& 1999, and Taiwan 1994, \& 2006; the World Bank does not recognize the countries for political reasons. We drop these country-wave pairs.

Finally, given that we are studying SWB inequality and that SWB inequality might be related to income inequality, we attempt to collect data regarding income inequality for the country-wave pairs in our dataset. There is income inequality data (Gini coefficient) in the WDI for only 127 of the country-wave pairs, and we could not find a more complete source of income inequality data than the WDI. Thus we use the Gini coefficient to measure of income inequality only as a robustness check. As our primary measure of income inequality, we use, for each country-wave pair, the standard deviation of WVS respondents' self-reported income decile into which their household falls. We have this measure of income inequality for 227 country-wave pairs; it is missing for the following pairs: Argentina 1984 \& 2006; Finland 1981; Hungary 1982 \& 1998; Jordan 2007; Philippines 1996; Portugal 1999; Slovenia 1995; and Sweden 1990.

Table 1 presents the countries that are included in the dataset, sorted by the average $\mathrm{SD}_{\mathrm{LS}}$ across all the waves; it also shows for each country the number of WVS waves that were administered, the first and last year the WVS was administered, and the mean of LS and GDPpc across all the waves. Interestingly, the vast majority of the countries with the lowest (highest) $\mathrm{SD}_{\mathrm{LS}}$ have high (low) GDPpc; the mean GDPpc of the 20 countries with the smallest (greatest) $\mathrm{SD}_{\mathrm{LS}}$ is above $\$ 20,000$ (below $\$ 2,000$ ). Pakistan is a clear exception to this pattern; it has the lowest $\mathrm{SD}_{\mathrm{LS}}$, 1.46, and has an average GDPpc of $\$ 526$. Further, the $\mathrm{SD}_{\mathrm{LS}}$ decreases (and GPDpc increases), as one progressively restricts the sample to OECD countries to country-wave pairs with GDPpc greater than $\$ 10,000$ and $\$ 20,000$; Table 2 presents the mean $S_{\mathrm{LS}}$, LS, and other characteristics for country-wave pairs).

\section{Results}

\footnotetext{
${ }^{3}$ Kalmijn and Veenhoven (2005) compare the effectiveness of eight SWB inequality measures, including a Gini coefficient, standard deviation, absolute mean difference, and inter-quartile range. After examining each statistic and empirically testing their sensitivity to various distributions, they determine that four statistics are adequate measures of SWB inequality, one of which is the standard deviation. Since the standard deviation is widely used and understood, we use it to measure SWB inequality.
} 
To examine the relationship between SWB inequality and income we first treat the data as repeated cross-sections. This analysis provides strong evidence that the two are negatively correlated, indicating that countries with higher income have lower SWB inequality. Next, we treat the data as time series. This analysis provides some evidence that countries with the greatest economic growth rates experience the greatest decrease in SWB inequality. However, the times-series analysis is far from conclusive.

\section{A. Cross-section analysis}

Figure 2a plots the $\mathrm{SD}_{\mathrm{LS}}$ and the Natural Log of GDPpc (LGDPpc) for each country-wave pair. There appears to be a negative relationship. That is, $\mathrm{SD}_{\mathrm{LS}}$ is smaller in country-wave pairs with greater LGDPpc (Figure 2b illustrates that the relationship is similar but less linear when one compares $\mathrm{SD}_{\mathrm{LS}}$ and GDPpc). Given that log income is generally used when studying the relationship between mean SWB and income, we use LGDPpc in the subsequent analysis, unless noted otherwise.

To estimate the relationship between SWB inequality and income, an equation of the following form is estimated:

$$
S D_{c-w}^{L S}=\alpha L G D P p c_{c-w}+\beta \bullet X_{c-w}+\varepsilon_{c-w}
$$

where $S D_{c-w}^{L S}$ is the $\mathrm{SD}_{\mathrm{LS}}$ for each country-wave pair, $c-w ; L G D P p c_{c-w}$ is the natural log of GDPpc in 2000 U.S. dollars for each $c$-w pair; and $X_{c-w}$ is a matrix of characteristics for each $c$-w pair including mean LS, age, income inequality, and percent of respondents who are female, married, childless, unemployed, and not high school graduates. Equation (1) is estimated using OLS using country fixed effects.

Estimating equation (1) without covariates, the coefficient on LGDPpc is negative and highly statistically significant, confirming the negative relationship between $\mathrm{SD}_{\mathrm{LS}}$ and LGDPpc that is apparent in Figure 2a (Column 1 of Table 3). Column 2 shows that this finding is robust to adding income inequality (using the SD of reported income), mean LS, and the other regressors discussed above (results from the progressive addition of these regressors are shown in Table 4). The magnitude of the coefficient indicates that doubling GDPpc is associated with a 0.19 reduction in $\mathrm{SD}_{\mathrm{LS}}$, or a nine percent $(=0.19 / 2.14)$ reduction from mean $\mathrm{SD}_{\mathrm{LS}}$. This is equivalent to moving from $46^{\text {th }}$ (Chile, $\mathrm{SD}_{\mathrm{LS}}=2.14$ ) to $27^{\text {th }}$ (New Zealand, $\mathrm{SD}_{\mathrm{LS}}=1.95$ ) in the $\mathrm{SWB}$ inequality ranking. The coefficient on income inequality is positive but statistically insignificant, which indicates that the negative relationship between $\mathrm{SD}_{\mathrm{LS}}$ and GDPpc is not simply an artifact of a negative relationship between GDPpc and income inequality. Finally, the coefficient on mean LS is negative and statistically significant, indicating that as mean LS increases, $\mathrm{SD}_{\mathrm{LS}}$ decreases. These results are not driven by the transition economies: Columns 3 and 4 of Table 3 show that the result is robust to, and indeed strengthened by, the exclusion of transition countries. 
The above analysis is repeated, using the 127 country-wave pairs with Gini information. Table 5 compares the coefficients on LGDPpc and income inequality using as measures of income inequality the SD of reported income (as in Table 3) and the country-wave Gini coefficient. While the restricted sample entails a loss of statistical power when other covariates are added (Columns 4 and 5 of Table 5), the coefficient on LGDPpc is stable across specifications (ranging from -0.225 to -0.314 ) and statistically significant in the absence of covariates (Columns 2 and 3). Thus the results appear robust to the choice of income-inequality metric.

To determine whether the decrease in $\mathrm{SD}_{\mathrm{LS}}$ associated with greater GDPpc results from fewer reports of "low LS" or "high LS," we estimate equation (1) with corresponding binary variables

in place of $S D_{c-w}^{L S}$. Specifically, Low $L S$, equals one if LS equals 1, 2, 3, or 4, and zero otherwise, and High LS equals one if LS is 9 or 10, and zero otherwise. Higher GDPpc is associated with a statistically significant reduction in low LS. With country fixed effects and no other covariates, doubling GDPpc is associated with a 9.2 percentage point reduction in a respondent's likelihood of reporting low LS (Column 1 of Table 6). The corresponding specification shows no statistically significant relationship between GDPpc and high LS (Column 4). Next, in columns 2 and 5, we include the controls described above; importantly, these include mean LS, which is known to be a positive correlate of income in cross-sectional analysis. A noteworthy result emerges: now, higher GDPpc is associated with a statistically significant decrease in both low and high LS (Columns 2 and 5). Interestingly, as GDPpc increases, high LS decreases, indicating that after controlling for mean LS, high LS actually decreases with GDPpc. Excluding transition countries increases the magnitude of the LGDPpc coefficient (Columns 3 and 6), indicating that the pooled results are not driven by these countries.

Finally, as shown in Table 7, restricting the sample to more developed countries, either the OECD countries or those countries with GPDpc greater than $\$ 10,000$ or $\$ 20,000$, increases the magnitude of the coefficient on LGDPpc. This indicates that the negative relationship between $\mathrm{SD}_{\mathrm{LS}}$ and GDPpc is more negative for higher income countries.

\section{B. Time-series analysis}

The negative relationship between SWB inequality and income that is apparent in cross-sectional analysis may or may not persist in time-series analysis. To investigate we examine the evolution over time of $\mathrm{SD}_{\mathrm{LS}}$ and GDPpc in individual countries. First we focus on countries with the longest time series, that is, the ten countries for which we have fives waves of LS data, providing a 22+ year time series for each: Argentina, Finland, Germany, Japan, Mexico, South Africa, Spain, Sweden, the United Kingdom, and the United States. Of these countries, all experience weakly increasing GDPpc over the time period. Figure 3 presents the time series of GDPpc and $\mathrm{SD}_{\mathrm{LS}}$ for the United States.

We calculate the average annual percent change in the $\mathrm{SD}_{\mathrm{LS}}$ and GDPpc between the first and last observation for each country. For example, 


$$
A v g \% \Delta S D_{c}^{L S}=\left.\left(\frac{S D_{c, w=5}^{L S}-S D_{C, w=1}^{L S}}{S D_{c, w=1}^{L S}}\right)\right|_{y e a r S_{C}}
$$

where year $_{c}$ is the number of years country, $c$, is in the time series. Figure 4 presents the scatterplot of these calculations for the ten countries that administered the WVS in all five waves. There appears to be a negative relationship, indicating that countries that experience the greatest average per-capita growth rate experience the greatest reduction in $\mathrm{SD}_{\mathrm{LS}}$.

Regressing $A v g \% \Delta S D_{c}^{L S}$ on $A v g \% \Delta G D P p c_{c}$, one finds a negative but statistically insignificant relationship (Column 1 of Table 8). However, the number of observations is small and there is one clear outlier, Finland (see Figure 4). Dropping Finland, one finds that the coefficient remains negative, grows in magnitude, and is statistically significant; this holds in the simple regression and with controls for the average annual percent change in SD of reported income and mean LS (Columns 2 and 3). In summary, there is evidence that the countries that experience the greatest per capita economic growth also experience the greatest decrease in $\mathrm{SD}_{\mathrm{LS}}$. The magnitude of the coefficient indicates that if GDPpc doubles, then $\mathrm{SD}_{\mathrm{LS}}$ will decrease by 20-30 percent. This is equivalent to moving from 46th (Chile, $\mathrm{SD}_{\mathrm{LS}}=2.14$ ) to 6th (Switzerland, $\mathrm{SD}_{\mathrm{LS}}$ $=1.73$ ) in the SWB inequality ranking.

Broadening the analysis to include countries with at least four waves of LS data provides a 12+ year time series for 25 countries (additional countries include Bulgaria, Canada, Chile, China, France, Hungary, Italy, Korea (South), Netherlands, Norway, Poland, Romania, Russia, Slovenia, and Turkey). Now there is a positive relationship between $A v g \% \Delta S D_{c}^{L S}$ and $A v g \% \Delta G D P p c_{c}$, as illustrated with the red line in Figure 5. However, there are two outliers, China and Korea, whose growth rates are each more than twice as large as the next fastest growing economies. Dropping the greatest outlier, China, from the figure materially changes the best-fit relationship (green line, Figure 5) to a negative one. Further, if one drops Korea, the country with next fastest growth rate, then the negative relationship becomes greater (yellow line, Figure 5). In the next section, we briefly discuss why unusually high growth rates may be associated with increased $\mathrm{SD}_{\mathrm{LS}}$.

Regressing $A v g \% \Delta S D_{c}^{L S}$ on $A v g \% \Delta G D P p c_{c}$ for the countries in at least four waves of the WVS, one finds negative and statistically significant relationship with China and Korea excluded (Column 4 of Table 8). This result holds with the inclusion of controls for the average annual percent changes in both SD of reported income and mean LS. That is, excluding the two countries with the greatest economic growth rates, it appears that countries experiencing greater economic growth also experience greater decreases in $\mathrm{SD}_{\mathrm{LS}}$. An alternative explanation, for which we have no statistically significant support, is that, in time series, there is a U-shaped relationship between economic growth and changes in $\mathrm{SD}_{\mathrm{LS}}$, wherein China and Korea lie on the upward-sloping part of the U. 


\section{Discussion}

We present evidence that there is a negative relationship between SWB inequality and income in cross-sectional analysis; this result is stable regardless of the covariates included in the analysis. The results indicate that the doubling of income is associated with a nine percent reduction in $\mathrm{SD}_{\mathrm{LS}}$, our measure of SWB inequality, from the mean. There is also time-series evidence that for most countries, greater economic growth rates will also be associated with greater declines in SWB inequality over time. The results indicate that doubling income is associated with a 20-30 percent decrease in SWB inequality. Interestingly this pattern is contradicted for the two countries in the dataset with the greatest economic growth rates: China and Korea. Perhaps, exceptional economic growth rates do not lead to decreasing SWB inequality over time, as such growth rates might cause large changes that affect citizens' SWB in disparate ways. Such a relationship is corroborated for China in Easterlin et al. (2012), which documents that those people in the bottom third of the income distribution were most hard-hit by the reduced job security, and associated benefits thereof, entailed by SOE restructuring.

The decrease in SWB inequality associated with economic growth seems to be associated with a decrease in low LS. This contrasts sharply with the recent positive correlation of economic growth and income inequality. For example, the United States and the United Kingdom have each experienced well-documented increases in income inequality during recent periods of economic growth. In contrast, economic growth appears to be negatively associated with high LS. The investigation of why greater income is associated with a compression of the LS distribution-e.g., hedonic adaptation (DiTella, Hasken-De New, and MacCulloch 2010) and negative side effects of attaining increased income on the high-LS end of the distribution, and improved social safety nets at the low-LS end of the distribution-is left for future research. To this end, Easterlin (1995) illustrates the relationship between social safety nets and mean LS.

Because our results are for the most part consistent across cross-sectional and time-series analyses, they do not present the challenge that the Easterlin paradox does. Our research also suggests that, despite the controversy the Easterlin paradox presents, there may be an additional benefit - insofar as SWB equality is desirable — associated with increased per capita income within a country: namely, decreasing SWB inequality. 


\section{References}

Atkinson AB (1970) On the measurement of inequality. J Econ Theory 2: 244-263.

Clark AE, Flèche S, Senik C (2012) The great happiness moderation. Paper presented at the CEPREMAP-PSE-DIMeco Conference Happiness and Economic Growth: Lessons from Developing Countries, Paris, March 9, 2012.

Diener E, Seligman MEP (2004) Beyond money: Toward an economy of well-being. Psychol Sci Public Interest 5: 1-31.

Di Tella, Haisken-De New J, MacCulloch R (2010) Happiness adaptation to income and to status in an individual panel. $J$ Econ Behav Organ 76: 834-852.

Easterlin RA (1974) in Nations and Households in Economic Growth: Essays in Honor of Moses Abramowitz, eds David PA, Reder MW (Academic Press, New York), pp 89-125.

Easterlin RA (1995) Will raising the incomes of all increase the happiness of all? J Econ Behav Organ 27: 35-47.

Easterlin RA (2012) Life satisfaction of rich and poor under socialism and capitalism. International Journal of Happiness and Development 1: 112-126.

Easterlin RA (2013) Happiness, growth, and public policy. Econ Inq 51: 1-15.

Easterlin RA, McVey LA, Switek M, Sawangfa O, Zweig JS (2010) The happiness-income paradox revisited. Proc Natl Acad Sci U S A 107: 22463-22468.

Easterlin RA, Morgan R, Switek M, Wang F (2012) China's life satisfaction: 1990-2010. Proc Natl Acad Sci U S A 109: 9775-9780.

Easterlin RA, Sawangfa O (2010) in International Differences in Well-Being, eds Diener E, Helliwell J, Kahneman D (Princeton University Press, Princeton), pp 162-212.

Gastwirth JL (1972) The estimation of the Lorenz curve and Gini index. Rev Econ Stat 54: 306316.

Gini C (1921) Measurement of inequality of incomes. Econ J 31: 124-126.

Gottschalk P, Smeeding T (1997) Cross-national comparisons of earnings and income inequality. J Econ Lit 35: 633-688.

Kahneman D, Krueger AB (2006) Developments in the measurement of subjective well-being. $J$ Econ Perspect 20: 3-24. 
Kalmijn W, Veenhoven R (2005) Measuring inequality of happiness in nations: In search for proper statistics. J Happiness Stud 6: 357-396.

Kuznets S (1955) Economic growth and income inequality. Am Econ Rev 45: 1-28.

Lorenz MO (1905) Methods of measuring the concentration of wealth. Publications of the American Statistical Association 9: 209-219.

Ott J (2005) Level and inequality of happiness in nations: Does greater happiness of a greater number imply greater inequality in happiness? J Happiness Stud 6: 397-420.

Stevenson B, Wolfers J (2008a) Economic growth and subjective well-being: Reassessing the Easterlin paradox. Brookings Pap Econ Act 39: 1-102.

Stevenson B, Wolfers J (2008b) Happiness inequality in the United States. J Legal Stud 37: 533579.

Stevenson B, Wolfers, J (2013) Subjective well-being and income: Is there any evidence of satiation? Am Econ Rev: Papers and Proceedings 103: 598-604.

Stiglitz JE, Sen A, Fitoussi J-P (2010) Mis-Measuring Our Lives (The New Press, New York). Veenhoven R (2005a) Return of inequality in modern society? Test by dispersion of lifesatisfaction across time and nations. J Happiness Stud 6: 457-487.

Veenhoven R (2005b) Inequality of happiness in nations. J Happiness Stud 6: 351-355.

Veenhoven R, Kalmijn W (2005) Inequality-adjusted happiness in nations: Egalitarianism and utilitarianism married in a new index of societal performance. J Happiness Stud 6: 421-455.

The World Bank World Development Indicators, (The World Bank, Washington, DC).

World Values Survey 1981-2008 Official Aggregate v.20090901, 2009. World Values Survey Association (www.worldvaluessurvey.org). Aggregate File Producer: ASEP/JDS, Madrid. 
Table 1: Countries in WVS sorted by the standard deviation of life satisfaction $(\mathrm{n}=97)$

\begin{tabular}{|c|c|c|c|c|c|c|}
\hline \multirow[b]{2}{*}{ Country } & \multicolumn{3}{|c|}{ Administered } & \multicolumn{3}{|c|}{ Across all wave } \\
\hline & $\begin{array}{c}\# \\
\text { waves } \\
\end{array}$ & $\begin{array}{l}\text { First } \\
\text { year }\end{array}$ & $\begin{array}{l}\text { Last } \\
\text { year }\end{array}$ & $\begin{array}{c}\text { Mean } \\
\text { LS }\end{array}$ & $\begin{array}{l}\text { SD of } \\
\text { LS }\end{array}$ & $\begin{array}{c}\text { GDPpc } \\
\text { (2000usd) }\end{array}$ \\
\hline Pakistan^ & 2 & 1997 & 2001 & 4.85 & 1.46 & 526 \\
\hline Netherlands $\wedge$ & 4 & 1981 & 2006 & 7.77 & 1.48 & 20,986 \\
\hline Iceland $\wedge \wedge \wedge \wedge$ & 3 & 1984 & 1999 & 8.04 & 1.60 & 26,674 \\
\hline Andorra $\wedge \wedge \wedge \wedge$ & 1 & 2005 & 2005 & 7.14 & 1.62 & 20,783 \\
\hline Finland $\wedge \wedge \wedge \wedge$ & 5 & 1981 & 2005 & 7.81 & 1.65 & 21,002 \\
\hline Switzerland $\wedge$ $\wedge \wedge$ & 3 & 1989 & 2007 & 8.10 & 1.73 & 34,130 \\
\hline Sweden $\wedge \wedge \wedge \wedge$ & 5 & 1982 & 2006 & 7.82 & 1.75 & 25,133 \\
\hline Norway^M^ & 4 & 1982 & 2008 & 7.80 & 1.75 & 31,561 \\
\hline Canada $\wedge M M$ & 4 & 1982 & 2006 & 7.82 & 1.77 & 21,370 \\
\hline Malaysia & 1 & 2006 & 2006 & 6.84 & 1.79 & 4,792 \\
\hline Singapore $\wedge \wedge \wedge \wedge$ & 1 & 2002 & 2002 & 7.24 & 1.80 & 22,571 \\
\hline Thailand ${ }^{\wedge} \wedge \wedge \wedge$ & 1 & 2007 & 2007 & 7.21 & 1.81 & 2,592 \\
\hline Australia $\wedge \wedge \wedge \wedge$ & 3 & 1981 & 2005 & 7.59 & 1.81 & 18,623 \\
\hline Northern Ireland $\wedge \wedge, \wedge \wedge \wedge$ & 3 & 1981 & 1999 & 7.85 & 1.82 & - \\
\hline Malta $\wedge \wedge \wedge \wedge$ & 3 & 1983 & 1999 & 8.15 & 1.84 & 7,079 \\
\hline Denmark ${ }^{\wedge \wedge \wedge \wedge}$ & 3 & 1981 & 1999 & 8.21 & 1.85 & 24,239 \\
\hline
\end{tabular}




\begin{tabular}{|c|c|c|c|c|c|c|}
\hline Spain $\wedge \wedge \wedge \wedge$ & 5 & 1981 & 2007 & 6.94 & 1.86 & 12,468 \\
\hline Japan $\wedge \wedge \wedge \wedge$ & 5 & 1981 & 2005 & 6.64 & 1.86 & 33,814 \\
\hline Luxembourg & 1 & 1999 & 1999 & 7.81 & 1.87 & 43,421 \\
\hline United Kingdom $\wedge \wedge \wedge \wedge$ & 5 & 1981 & 2006 & 7.52 & 1.87 & 22,304 \\
\hline United States $\wedge \wedge \wedge$ & 5 & 1982 & 2006 & 7.60 & 1.88 & 30,375 \\
\hline Austria $\wedge M \wedge$ & 2 & 1990 & 1999 & 7.95 & 1.88 & 21,188 \\
\hline Ireland $\wedge \wedge \wedge \wedge$ & 3 & 1981 & 1999 & 7.96 & 1.88 & 15,894 \\
\hline Hong Kong $\wedge \wedge \wedge \wedge$ & 1 & 2005 & 2005 & 6.41 & 1.93 & 30,395 \\
\hline Germany $\wedge \wedge \wedge \wedge$ & 5 & 1981 & 2006 & 7.10 & 1.94 & 20,719 \\
\hline Belgium $\wedge \wedge \wedge \wedge$ & 3 & 1981 & 1999 & 7.47 & 1.94 & 18,745 \\
\hline New Zealand $\wedge \wedge \wedge \wedge$ & 2 & 1998 & 2004 & 7.80 & 1.95 & 13,513 \\
\hline Colombia & 2 & 1997 & 2005 & 8.31 & 1.97 & 2,579 \\
\hline Vietnam & 2 & 2001 & 2006 & 6.81 & 1.98 & 500 \\
\hline France $\mathrm{e}^{\wedge \wedge \wedge \wedge}$ & 4 & 1981 & 2006 & 6.84 & 1.99 & 19,739 \\
\hline 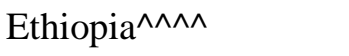 & 1 & 2007 & 2007 & 4.99 & 2.01 & 175 \\
\hline Taiwan^^, $\wedge \wedge \wedge$ & 2 & 1994 & 2006 & 6.61 & 2.02 & - \\
\hline Cyprus $\wedge \wedge \wedge \wedge$ & 1 & 2006 & 2006 & 7.35 & 2.03 & 14,719 \\
\hline Albania & 2 & 1998 & 2002 & 4.97 & 2.03 & $\$ 1,167$ \\
\hline Portugal $\wedge \wedge M$ & 2 & 1990 & 1999 & 7.05 & 2.05 & 9,609 \\
\hline \multirow[b]{2}{*}{ Country } & \multicolumn{3}{|c|}{ Administered } & \multicolumn{3}{|c|}{ Across all wave } \\
\hline & $\begin{array}{c}\# \\
\text { waves }\end{array}$ & $\begin{array}{l}\text { First } \\
\text { year }\end{array}$ & $\begin{array}{l}\text { Last } \\
\text { year }\end{array}$ & $\begin{array}{c}\text { Mean } \\
\text { LS }\end{array}$ & $\begin{array}{c}\text { SD of } \\
\text { LS }\end{array}$ & $\begin{array}{c}\text { GDPpc } \\
\text { (2000usd) }\end{array}$ \\
\hline
\end{tabular}




\begin{tabular}{|c|c|c|c|c|c|c|}
\hline Czech Republic $\wedge \wedge \wedge, \wedge \wedge \wedge \wedge$ & 3 & 1990 & 1999 & 6.72 & 2.06 & 5,301 \\
\hline Uruguay & 2 & 1996 & 2006 & 7.30 & 2.07 & 7,127 \\
\hline Guatemala & 1 & 2005 & 2005 & 7.95 & 2.09 & 1,762 \\
\hline Puerto Rico $\wedge \wedge \wedge \wedge$ & 2 & 1995 & 2001 & 8.30 & 2.09 & 15,178 \\
\hline Italy $\wedge \wedge \wedge \wedge$ & 4 & 1981 & 2005 & 7.00 & 2.10 & 16,971 \\
\hline Мexico $\wedge \wedge \wedge \wedge$ & 5 & 1981 & 2005 & 7.86 & 2.10 & 5,515 \\
\hline Indonesia $\wedge \wedge \wedge \wedge$ & 2 & 2001 & 2006 & 6.93 & 2.11 & 905 \\
\hline Slovenia^^^ & 4 & 1992 & 2005 & 6.81 & 2.11 & 9,184 \\
\hline Rwanda $\wedge \wedge \wedge \wedge$ & 1 & 2007 & 2007 & 4.97 & 2.11 & 290 \\
\hline Argentina & 5 & 1984 & 2006 & 7.19 & 2.13 & 7,348 \\
\hline Chile & 4 & 1990 & 2005 & 7.21 & 2.14 & 4,530 \\
\hline Morocco & 2 & 2001 & 2007 & 5.66 & 2.17 & 1,499 \\
\hline Israel & 1 & 2001 & 2001 & 7.03 & 2.17 & 19,366 \\
\hline Burkina Faso ${ }^{\wedge} \wedge \wedge$ & 1 & 2007 & 2007 & 5.57 & 2.18 & 260 \\
\hline Greece & 1 & 1999 & 1999 & 6.67 & 2.19 & 11,043 \\
\hline Estonia $\wedge \wedge \wedge$ & 3 & 1990 & 1999 & 5.64 & 2.20 & 3,535 \\
\hline Korea (South) $)^{\wedge}, \wedge \wedge \wedge$ & 5 & 1982 & 2005 & 6.16 & 2.20 & 9,247 \\
\hline Bangladesh & 2 & 1996 & 2002 & 6.09 & 2.21 & 324 \\
\hline
\end{tabular}




\begin{tabular}{|c|c|c|c|c|c|c|}
\hline Belarus^^^ & 3 & 1990 & 2000 & 4.89 & 2.22 & 1,211 \\
\hline Croatia & 2 & 1996 & 1999 & 6.43 & 2.22 & 4,421 \\
\hline Trinidad And Tobago $\wedge \wedge \wedge \wedge$ & 1 & 2006 & 2006 & 7.26 & 2.23 & 10,217 \\
\hline Saudi Arabia $\wedge \wedge \wedge \wedge$ & 1 & 2003 & 2003 & 7.28 & 2.27 & 9,266 \\
\hline Azerbaijan & 1 & 1997 & 1997 & 5.39 & 2.29 & 513 \\
\hline Slovak Republic $\wedge \wedge \wedge, \wedge \wedge \wedge \wedge$ & 3 & 1990 & 1999 & 6.24 & 2.29 & 5,236 \\
\hline Bosnia And Herzegovina $\wedge \wedge \wedge \wedge$ & 2 & 1998 & 2001 & 5.61 & 2.30 & 1,407 \\
\hline Serbia $\wedge M \wedge$ & 3 & 1996 & 2006 & 5.77 & 2.31 & 1,368 \\
\hline Poland $\wedge \wedge, \wedge \wedge \wedge$ & 4 & 1989 & 2005 & 6.55 & 2.32 & 4,112 \\
\hline Moldova & 3 & 1996 & 2006 & 4.58 & 2.33 & 427 \\
\hline $\operatorname{China}^{\wedge \wedge \wedge,} \wedge \wedge \wedge \wedge$ & 4 & 1990 & 2007 & 6.85 & 2.35 & 970 \\
\hline Latvia^M & 3 & 1990 & 1999 & 5.29 & 2.35 & 3,148 \\
\hline Peru & 3 & 1996 & 2008 & 6.61 & 2.35 & 2,309 \\
\hline Armenia & 1 & 1997 & 1997 & 4.32 & 2.37 & 520 \\
\hline Hungary $\wedge \wedge \wedge, \wedge \wedge \wedge \wedge$ & 4 & 1982 & 1999 & 6.15 & 2.39 & 4,103 \\
\hline Ukraine & 3 & 1996 & 2006 & 4.77 & 2.39 & 747 \\
\hline Brazil & 3 & 1991 & 2006 & 7.39 & 2.40 & 3,712 \\
\hline$\underline{\operatorname{Iran} \wedge \wedge \wedge \wedge}$ & 2 & 2000 & 2007 & 6.40 & 2.41 & 1,861 \\
\hline \multirow[b]{2}{*}{ Country } & \multicolumn{3}{|c|}{ Administered } & \multicolumn{3}{|c|}{ Across all wave } \\
\hline & $\begin{array}{c}\# \\
\text { waves } \\
\end{array}$ & $\begin{array}{l}\text { First } \\
\text { year }\end{array}$ & $\begin{array}{l}\text { Last } \\
\text { year }\end{array}$ & $\begin{array}{c}\text { Mean } \\
\text { LS } \\
\end{array}$ & $\begin{array}{c}\text { SD of } \\
\text { LS }\end{array}$ & $\begin{array}{c}\text { GDPpc } \\
\text { (2000usd) }\end{array}$ \\
\hline Bulgaria $\wedge \wedge \wedge$ & 4 & 1990 & 2006 & 5.10 & 2.41 & 1,697 \\
\hline
\end{tabular}




\begin{tabular}{|c|c|c|c|c|c|c|}
\hline $\operatorname{Iraq}^{\wedge \wedge \wedge \wedge}$ & 2 & 2004 & 2006 & 4.84 & 2.41 & 711 \\
\hline El Salvador & 1 & 1999 & 1999 & 7.50 & 2.43 & 2,174 \\
\hline Georgia & 2 & 1996 & 2008 & 4.82 & 2.43 & 891 \\
\hline Philippines & 2 & 1996 & 2001 & 6.75 & 2.44 & 951 \\
\hline Macedonia & 2 & 1998 & 2001 & 5.41 & 2.45 & 1,673 \\
\hline Dominican Republic & 1 & 1996 & 1996 & 7.13 & 2.47 & 2,227 \\
\hline Uganda & 1 & 2001 & 2001 & 5.65 & 2.47 & 258 \\
\hline Russian Federation $\wedge \wedge \wedge, \wedge \wedge \wedge$ & 4 & 1990 & 2006 & 5.16 & 2.48 & 2,120 \\
\hline Romania $^{\wedge} \wedge$ & 4 & 1993 & 2005 & 5.43 & 2.49 & 1,767 \\
\hline Zambia^^^^ & 1 & 2007 & 2007 & 6.06 & 2.50 & 374 \\
\hline Turkey^^м & 4 & 1990 & 2007 & 6.41 & 2.50 & 3,992 \\
\hline Nigeria & 3 & 1990 & 2000 & 6.68 & 2.52 & 362 \\
\hline Lithuania $\wedge \wedge \wedge$ & 3 & 1990 & 1999 & 5.40 & 2.54 & 3,458 \\
\hline South Africa ${ }^{\wedge} \wedge \wedge$ & 5 & 1982 & 2007 & 6.62 & 2.56 & 3,279 \\
\hline Kyrgyz Republic & 1 & 2003 & 2003 & 6.48 & 2.57 & 306 \\
\hline Mali & 1 & 2007 & 2007 & 6.09 & 2.59 & 287 \\
\hline Ghana & 1 & 2007 & 2007 & 6.12 & 2.63 & 313 \\
\hline Jordan & 2 & 2001 & 2007 & 6.40 & 2.65 & 2,091 \\
\hline Venezuela & 2 & 1996 & 2000 & 7.12 & 2.75 & 4,912 \\
\hline Zimbabwe $^{\wedge \wedge \wedge \wedge}$ & 1 & 2001 & 2001 & 3.95 & 2.79 & 576 \\
\hline Algeria & 1 & 2002 & 2002 & 5.67 & 2.86 & 1,874 \\
\hline Egypt $\wedge \wedge \wedge \wedge$ & 2 & 2000 & 2008 & 5.57 & 3.02 & 1,604 \\
\hline Tanzania & 1 & 2001 & 2001 & 3.87 & 3.22 & 283 \\
\hline
\end{tabular}

^ Missing LS data from WVS: Korea 1996; and Pakistan 1997.

$\wedge \wedge$ Missing GDPpc from WDI: Northern Ireland 1981, 1990, \& 1999; and Taiwan 1994 \& 2006. Poland 1989 GDPpc data from 1990 (1989 data missing).

$\wedge \wedge$ Transition country.

$\wedge \wedge \wedge$ Missing Gini coefficient from WDI for at least one wave. 
Table 2: Mean characteristics by country-wave pairs

\begin{tabular}{|c|c|c|c|c|c|c|c|c|}
\hline \multirow[b]{2}{*}{ Mean LS } & \multicolumn{2}{|c|}{$\begin{array}{l}\text { All } \\
(1)\end{array}$} & \multicolumn{2}{|c|}{$\begin{array}{c}\text { OECD } \\
(2)\end{array}$} & \multicolumn{2}{|c|}{$\begin{array}{c}\text { GDPpc }> \\
\$ 10,000 \\
(3)\end{array}$} & \multicolumn{2}{|c|}{$\begin{array}{c}\text { GDPpc }> \\
\$ 20,000 \\
(4)\end{array}$} \\
\hline & 6.69 & $(0.07)$ & 7.23 & $(0.06)$ & 7.48 & $(0.05)$ & 7.55 & $(0.07)$ \\
\hline $\mathrm{SD}_{\mathrm{LS}}$ & 2.14 & $(0.02)$ & 1.96 & $(0.02)$ & 1.85 & $(0.02)$ & 1.80 & $(0.02)$ \\
\hline GDPpc (in 2000usd) & $\$ 10,283$ & (691) & $\$ 17,154$ & $(945)$ & $\$ 22,201$ & (813) & $\$ 27,509$ & (848) \\
\hline Income inequality $^{+}$ & 2.22 & $(0.03)$ & 2.37 & $(0.04)$ & 2.41 & $(0.04)$ & 2.50 & $(0.06)$ \\
\hline Age & 42.07 & (0.39) & 44.00 & $(0.47)$ & 44.56 & $(0.55)$ & 45.73 & $(0.88)$ \\
\hline Female & 0.52 & $(0.00)$ & 0.52 & $(0.00)$ & 0.53 & $(0.00)$ & 0.52 & $(0.00)$ \\
\hline Married & 0.58 & $(0.01)$ & 0.58 & $(0.01)$ & 0.57 & $(0.01)$ & 0.56 & $(0.01)$ \\
\hline No children & 0.25 & $(0.01)$ & 0.23 & $(0.01)$ & 0.25 & $(0.01)$ & 0.27 & $(0.02)$ \\
\hline Unemployed & 0.08 & $(0.00)$ & 0.05 & $(0.00)$ & 0.05 & $(0.00)$ & 0.05 & $(0.00)$ \\
\hline $\begin{array}{l}\text { Did not complete } \\
\text { high school }\end{array}$ & 0.45 & $(0.01)$ & 0.45 & $(0.02)$ & 0.41 & $(0.03)$ & 0.43 & $(0.03)$ \\
\hline Number of countries & 93 & & 34 & & 32 & & 21 & \\
\hline $\begin{array}{l}\text { Number of country- } \\
\text { wave pairs }\end{array}$ & 237 & & 12 & & 90 & & 50 & \\
\hline
\end{tabular}

Standard error in parenthesis.

${ }^{+}$Standard deviation of reported income deciles 
Table 3: Ordinary least square estimates of equation (1) where the dependent variable is the standard deviation of life satisfaction

\begin{tabular}{|c|c|c|c|c|c|c|c|c|}
\hline \multirow[b]{2}{*}{ LGDPpc } & \multicolumn{2}{|c|}{$\begin{array}{l}\text { All } \\
(1)\end{array}$} & \multicolumn{2}{|l|}{$\begin{array}{l}\text { All } \\
(2)\end{array}$} & \multicolumn{2}{|c|}{$\begin{array}{c}\text { Non- } \\
\text { transition } \\
\text { countries } \\
(3)\end{array}$} & \multicolumn{2}{|c|}{$\begin{array}{c}\text { Non- } \\
\text { transition } \\
\text { countries } \\
(4) \\
\end{array}$} \\
\hline & $\begin{array}{r}-0.187 \\
(0.058)\end{array}$ & $* * *$ & $\begin{array}{c}-0.192 \\
(0.082)\end{array}$ & $* *$ & $\begin{array}{l}-0.255 \\
(0.072)\end{array}$ & $* * *$ & $\begin{array}{r}-0.351 \\
(0.116)\end{array}$ & $* * *$ \\
\hline Income inequality $^{+}$ & & & $\begin{array}{r}0.024 \\
(0.033)\end{array}$ & & & & $\begin{array}{r}0.019 \\
(0.042)\end{array}$ & \\
\hline Mean LS & & & $\begin{array}{r}-0.085 \\
(0.040)\end{array}$ & $* *$ & & & $\begin{array}{r}-0.086 \\
(0.052)\end{array}$ & $*$ \\
\hline \multicolumn{9}{|l|}{ Includes: } \\
\hline Country fixed effects & Yes & & Yes & & $\mathrm{Ye}$ & & Yes & \\
\hline Other covariates $^{++}$ & No & & Yes & & $\mathrm{Nc}$ & & Yes & \\
\hline Observations & 237 & & 237 & & 19 & & 191 & \\
\hline Number of countries & 93 & & 93 & & 80 & & 80 & \\
\hline
\end{tabular}

Standard errors in parenthesis.

$*$, **, $* * *$ signifies $\mathrm{p}<0.10,0.05,0.01$, respectively.

${ }^{+}$For each country-wave pair, the standard deviation of income.

${ }^{++}$For each country-wave pair, mean age; percent of respondents did not complete high school; and percent of respondents who are female, married, not parents, and unemployed. 
Table 4: Ordinary least square estimates of equation (1) where the dependent variable is the standard deviation of life satisfaction

\begin{tabular}{|c|c|c|c|c|c|c|c|c|c|c|c|c|c|c|}
\hline & \multirow{2}{*}{$\begin{array}{c}\begin{array}{c}\text { All } \\
(1)\end{array} \\
-0.157 \\
(0.016)\end{array}$} & \multirow[b]{2}{*}{$* * *$} & \multirow{2}{*}{$\begin{array}{c}\begin{array}{c}\text { All } \\
(2)\end{array} \\
-0.187 \\
(0.058)\end{array}$} & \multirow[b]{2}{*}{$* * *$} & \multicolumn{2}{|l|}{$\begin{array}{l}\text { All } \\
(3)\end{array}$} & \multicolumn{2}{|l|}{$\begin{array}{l}\text { All } \\
(4)\end{array}$} & \multicolumn{2}{|l|}{$\begin{array}{l}\text { All } \\
(5)\end{array}$} & \multicolumn{2}{|c|}{$\begin{array}{c}\text { Non-transition } \\
\text { countries } \\
\text { (6) }\end{array}$} & \multicolumn{2}{|c|}{$\begin{array}{c}\text { Non-transition } \\
\text { countries } \\
\text { (7) }\end{array}$} \\
\hline & & & & & $\begin{array}{r}-0.181 \\
(0.058)\end{array}$ & $* * *$ & $\begin{array}{r}-0.130 \\
(0.061)\end{array}$ & $* *$ & $\begin{array}{r}-0.192 \\
(0.082)\end{array}$ & $* *$ & $\begin{array}{r}-0.255 \\
(0.072)\end{array}$ & $* * *$ & $\begin{array}{r}-0.351 \\
(0.116)\end{array}$ & $* * *$ \\
\hline Income inequality $^{+}$ & & & & & $\begin{array}{r}0.045 \\
(0.033)\end{array}$ & & $\begin{array}{r}0.044 \\
(0.032)\end{array}$ & & $\begin{array}{r}0.024 \\
(0.033)\end{array}$ & & & & $\begin{array}{r}0.019 \\
(0.042)\end{array}$ & \\
\hline Mean LS & & & & & & & $\begin{array}{r}-0.084 \\
(0.037)\end{array}$ & $* *$ & $\begin{array}{r}-0.085 \\
(0.040)\end{array}$ & $* *$ & & & $\begin{array}{r}-0.086 \\
(0.052)\end{array}$ & $*$ \\
\hline \multicolumn{15}{|l|}{ Includes: } \\
\hline Country fixed effects & No & & Yes & & Yes & & Yes & & Yes & & Yes & & $\mathrm{Ye}$ & \\
\hline Other covariates $^{++}$ & No & & No & & No & & No & & Yes & & No & & $\mathrm{Ye}$ & \\
\hline Observations & 237 & & 237 & & 237 & & 237 & & 237 & & 191 & & 19 & \\
\hline Number of countries & 93 & & 93 & & 93 & & 93 & & 93 & & 80 & & 80 & \\
\hline
\end{tabular}

Standard errors in parenthesis.

$*$, **, *** signifies $\mathrm{p}<0.10,0.05,0.01$, respectively.

${ }^{+}$For each country-wave pair, the standard deviation of income.

${ }^{++}$For each country-wave pair, mean age; percent of respondents did not complete high school; and percent of respondents who are female, married, not parents, and unemployed. 
Table 5: Ordinary least square estimates of equation (1) where the dependent variable is the standard deviation of life satisfaction, using WDI data and comparing the standard deviation of reported income to the Gini coefficient

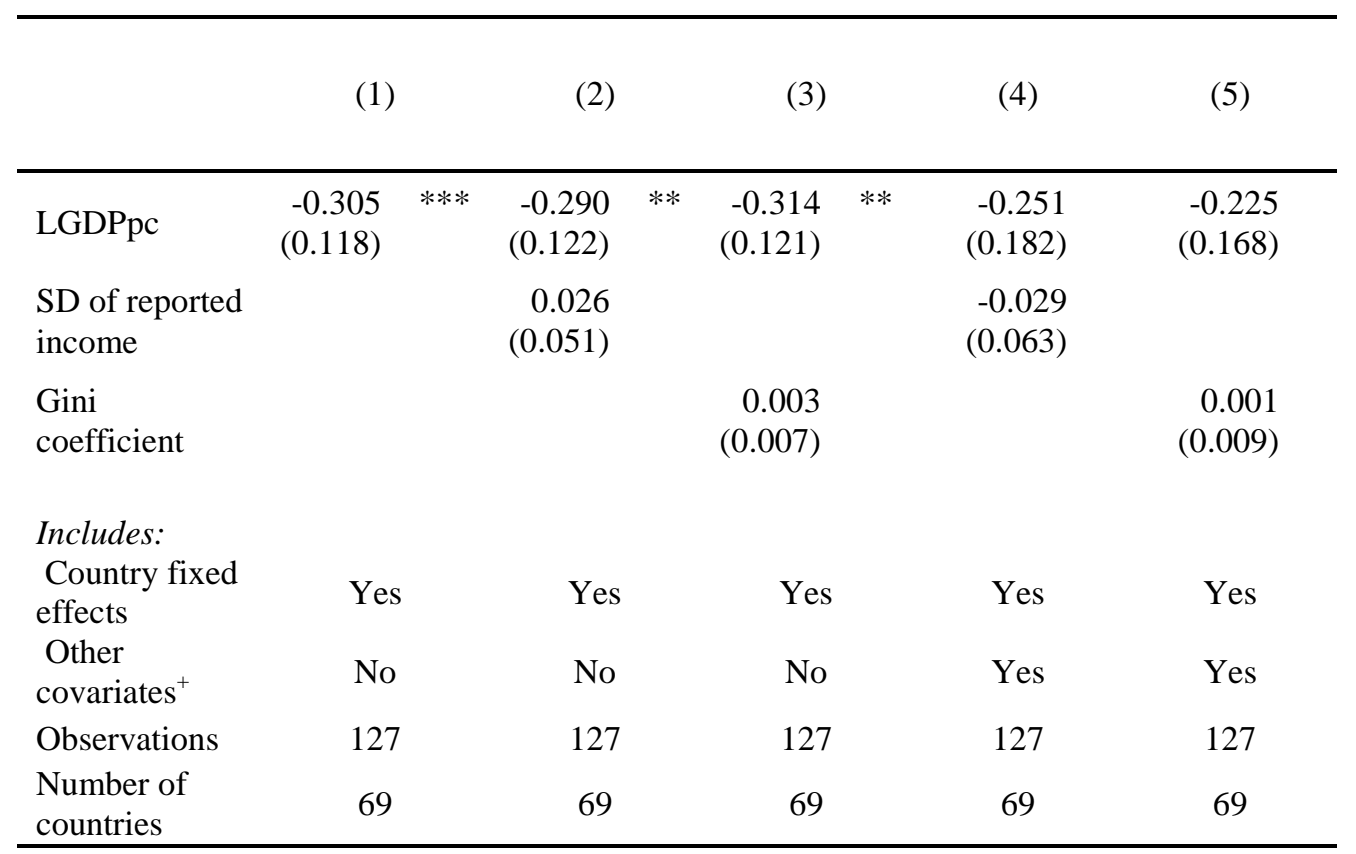

Standard errors in parenthesis.

$*$, **, $* * *$ signifies $\mathrm{p}<0.10,0.05,0.01$, respectively.

${ }^{+}$For each country-wave pair, mean LS, mean age, and percent of respondents who are female, married, not parents, unemployed, and not high school graduates. 
Table 6: Ordinary least square estimates of equation (1) where the dependent variable is low and high levels of life satisfaction

\begin{tabular}{|c|c|c|c|c|c|c|c|c|c|c|c|}
\hline \multirow[b]{2}{*}{ LGDPpc } & \multicolumn{2}{|c|}{$\begin{array}{l}\text { Low LS } \\
\text { (1) }\end{array}$} & \multicolumn{2}{|c|}{$\begin{array}{l}\text { Low LS } \\
\text { (2) }\end{array}$} & \multicolumn{2}{|c|}{$\begin{array}{c}\text { Low LS } \\
\text { Non-transition } \\
\text { countries } \\
\text { (3) }\end{array}$} & \multirow{2}{*}{$\begin{array}{l}\text { High LS } \\
\begin{array}{r}\text { (4) } \\
\\
0.015 \\
(0.019)\end{array}\end{array}$} & \multirow{2}{*}{$\begin{array}{l}\begin{array}{l}\text { High LS } \\
\text { (5) } \\
-0.060 \\
(0.019)\end{array}\end{array}$} & \multicolumn{3}{|c|}{$\begin{array}{c}\text { High LS } \\
\text { Non-transition } \\
\text { countries } \\
(6)\end{array}$} \\
\hline & $\begin{array}{r}-0.092 \\
(0.018)\end{array}$ & $* * *$ & $\begin{array}{r}-0.026 \\
(0.011)\end{array}$ & $* *$ & $\begin{array}{r}-0.032 \\
(0.015)\end{array}$ & $* *$ & & & $* * *$ & $\begin{array}{r}-0.087 \\
(0.028)\end{array}$ & $* * *$ \\
\hline $\begin{array}{l}\text { Income } \\
\text { inequality }^{+}\end{array}$ & & & $\begin{array}{r}0.009 \\
(0.005)\end{array}$ & $*$ & $\begin{array}{r}0.007 \\
(0.006)\end{array}$ & & & $\begin{array}{r}0.008 \\
(0.008)\end{array}$ & & $\begin{array}{r}0.010 \\
(0.010)\end{array}$ & \\
\hline Mean LS & & & $\begin{array}{r}-0.124 \\
(0.005)\end{array}$ & $* * *$ & $\begin{array}{r}-0.113 \\
(0.007)\end{array}$ & $* * *$ & & $\begin{array}{r}0.106 \\
(0.009)\end{array}$ & $* * *$ & $\begin{array}{r}0.120 \\
(0.013)\end{array}$ & $* * *$ \\
\hline $\begin{array}{l}\text { Includes: } \\
\text { Country fixed } \\
\text { effects }\end{array}$ & Yes & & Yes & & Yes & & Yes & Yes & & Yes & \\
\hline $\begin{array}{l}\text { Other } \\
\text { covariates }^{++}\end{array}$ & No & & Yes & & Yes & & No & No & & Yes & \\
\hline Observations & 237 & & 237 & & 191 & & 237 & 237 & & 191 & \\
\hline $\begin{array}{l}\text { Number of } \\
\text { countries }\end{array}$ & 93 & & 93 & & 80 & & 93 & 93 & & 80 & \\
\hline $\begin{array}{l}\text { Standard errors } \\
*, * *, * * * \text { signi } \\
{ }^{*} \text { For each coun }\end{array}$ & $\begin{array}{l}\text { nthesis. } \\
0.10,0 . \\
\text { ve pair, tl }\end{array}$ & 0 & $\begin{array}{l}\text { pectively } \\
\text { leviation }\end{array}$ & 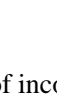 & & & & & & & \\
\hline
\end{tabular}


Table 7: Ordinary least square estimates of equation (1) where the dependent variable is the standard deviation of life satisfaction and sample is limited to OECD countries and also countries with high GDP per capita

\begin{tabular}{|c|c|c|c|c|c|c|c|}
\hline & $\begin{array}{l}\text { OECD } \\
\text { (1) }\end{array}$ & $\begin{array}{c}\text { OECD } \\
\text { (2) }\end{array}$ & $\begin{array}{c}\text { Per capita } \\
\text { income > } \\
\$ 10,000 \\
(3)\end{array}$ & $\begin{array}{c}\text { Per capita } \\
\text { income > } \\
\$ 10,000 \\
(4)\end{array}$ & $\begin{array}{c}\text { Per capita } \\
\text { income > } \\
\$ 20,000 \\
(5)\end{array}$ & $\begin{array}{c}\text { Per cap } \\
\text { income } \\
\$ 20,00 \\
(6)\end{array}$ & \\
\hline Log GDP per capita & $\begin{array}{l}-0.200 \quad * * * \\
(0.066)\end{array}$ & $\begin{array}{l}-0.318 \quad * * \\
(0.121)\end{array}$ & $\begin{array}{l}-0.214 * * \\
(0.086)\end{array}$ & $\begin{array}{l}-0.448 \quad * * \\
(0.157)\end{array}$ & $\begin{array}{l}-0.388 \quad * * * \\
(0.101)\end{array}$ & $\begin{array}{l}-0.530 \\
(0.171)\end{array}$ & $* * *$ \\
\hline Income inequality $^{+}$ & & $\begin{array}{r}0.008 \\
(0.037)\end{array}$ & & $\begin{array}{r}0.012 \\
(0.049)\end{array}$ & & $\begin{array}{r}0.044 \\
(0.051)\end{array}$ & \\
\hline Mean LS & & $\begin{array}{l}-0.156 \quad * * * \\
(0.048)\end{array}$ & & $\begin{array}{l}-0.299 \quad * * * \\
(0.096)\end{array}$ & & $\begin{array}{l}-0.222 \\
(0.109)\end{array}$ & * \\
\hline \multicolumn{8}{|l|}{ Includes: } \\
\hline Country fixed effects & Yes & Yes & Yes & Yes & Yes & Yes & \\
\hline Other covariates $^{++}$ & No & Yes & No & Yes & No & Yes & \\
\hline Observations & 120 & 120 & 90 & 90 & 50 & 50 & \\
\hline Number of countries & 34 & 34 & 32 & 32 & 21 & 21 & \\
\hline
\end{tabular}

Standard errors in parenthesis.

$*, * *, * * *$ signifies $\mathrm{p}<0.10,0.05,0.01$, respectively.

${ }^{+}$For each country-wave pair, the standard deviation of income.

${ }^{+++}$For each country-wave pair, mean age; percent of respondents did not complete high school; and percent of respondents who are female, married, not parents, and unemployed. 
Table 8: Ordinary least squares estimates of regressing the average annual change in the standard deviation of life satisfaction on average annual per capita GDP growth

\begin{tabular}{|c|c|c|c|c|c|c|c|}
\hline \multirow[b]{2}{*}{ Avg\% $\%$ GDPpс } & \multirow{2}{*}{$\begin{array}{c}\begin{array}{c}\text { In } 5 \\
\text { waves } \\
(1)\end{array} \\
-0.235 \\
(0.142)\end{array}$} & $\begin{array}{l}\text { In } 5 \text { waves, } \\
\text { except } \\
\text { Finland } \\
(2)\end{array}$ & \multicolumn{2}{|c|}{$\begin{array}{c}\text { In } 5 \text { waves, } \\
\text { except } \\
\text { Finland } \\
\text { (3) }\end{array}$} & $\begin{array}{l}\text { In 4+ waves, } \\
\text { except China } \\
\text { and Korea } \\
\text { (4) }\end{array}$ & \multicolumn{2}{|c|}{$\begin{array}{l}\text { In } 4+\text { waves, } \\
\text { except China, } \\
\text { and Korea } \\
\text { (5) }\end{array}$} \\
\hline & & $\begin{array}{r}-0.319 \\
(0.099)\end{array}$ & $\begin{array}{r}-0.315 \\
(0.118)\end{array}$ & $* *$ & $\begin{array}{rl}-0.164 & * * * \\
(0.046) & \end{array}$ & $\begin{array}{r}-0.181 \\
(0.049)\end{array}$ & *** \\
\hline $\begin{array}{l}\text { Avg\% } \Delta \text { Income } \\
\text { Inequality }\end{array}$ & & & $\begin{array}{r}0.306 \\
(0.247)\end{array}$ & & & $\begin{array}{r}0.054 \\
(0.034)\end{array}$ & \\
\hline $\begin{array}{l}\text { Avg\% } \% \text { Mean of } \\
\text { LS }\end{array}$ & & & $\begin{array}{r}-0.875 \\
(0.391)\end{array}$ & $*$ & & $\begin{array}{r}-0.414 \\
(0.169)\end{array}$ & $* *$ \\
\hline $\begin{array}{l}\text { Number of } \\
\text { countries }\end{array}$ & 10 & $9^{\wedge}$ & $9^{\wedge}$ & & 23 & $21^{\prime}$ & \\
\hline
\end{tabular}

Standard errors in parenthesis.

$*, * *, * * *$ signifies $\mathrm{p}<0.10,0.05,0.01$, respectively.

${ }^{+}$For each country-wave pair, percent change from first to last wave.

$\wedge$ Argentina (in 5 waves) and Hungary (in 4 waves) are dropped due to missing income inequality data. 
Figure 1a: Distribution of LS responses in WVS (341,198 observations)

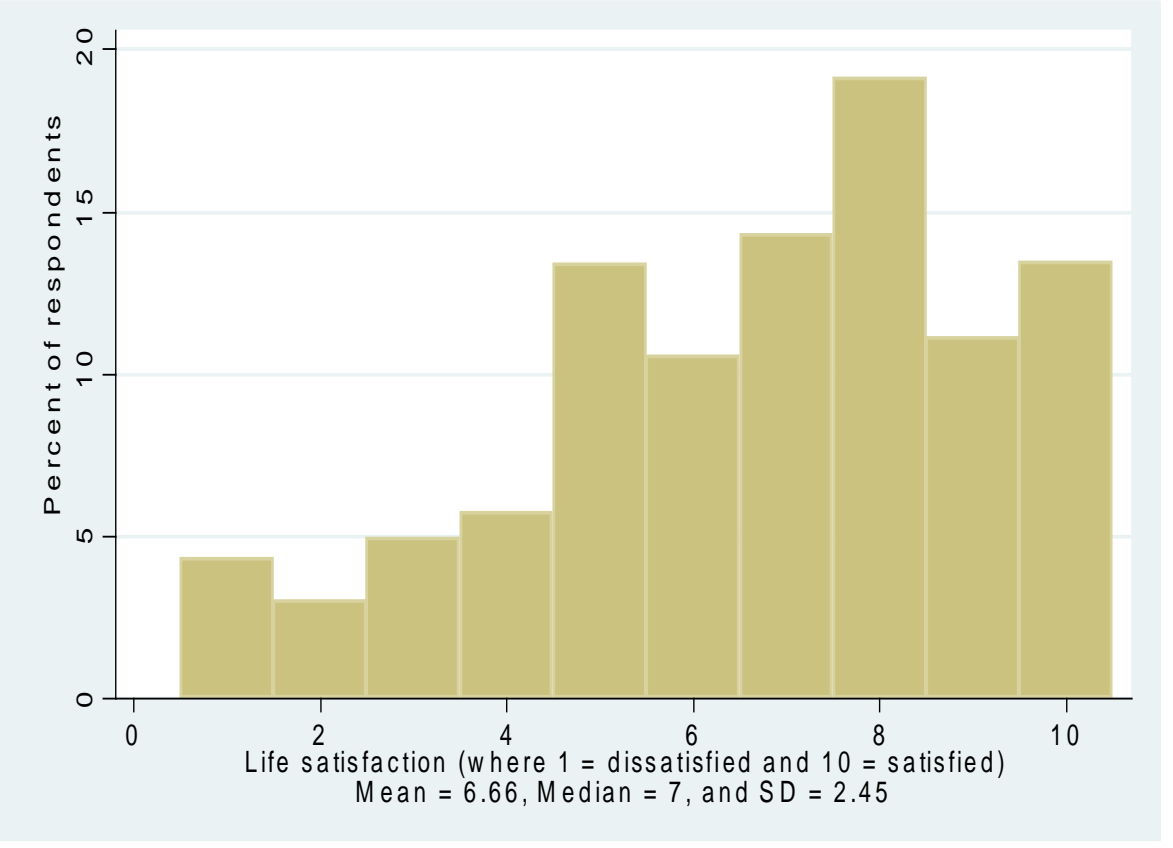

Figure 1b: Distribution of standard deviation of LS by country-wave pair (237 observations)

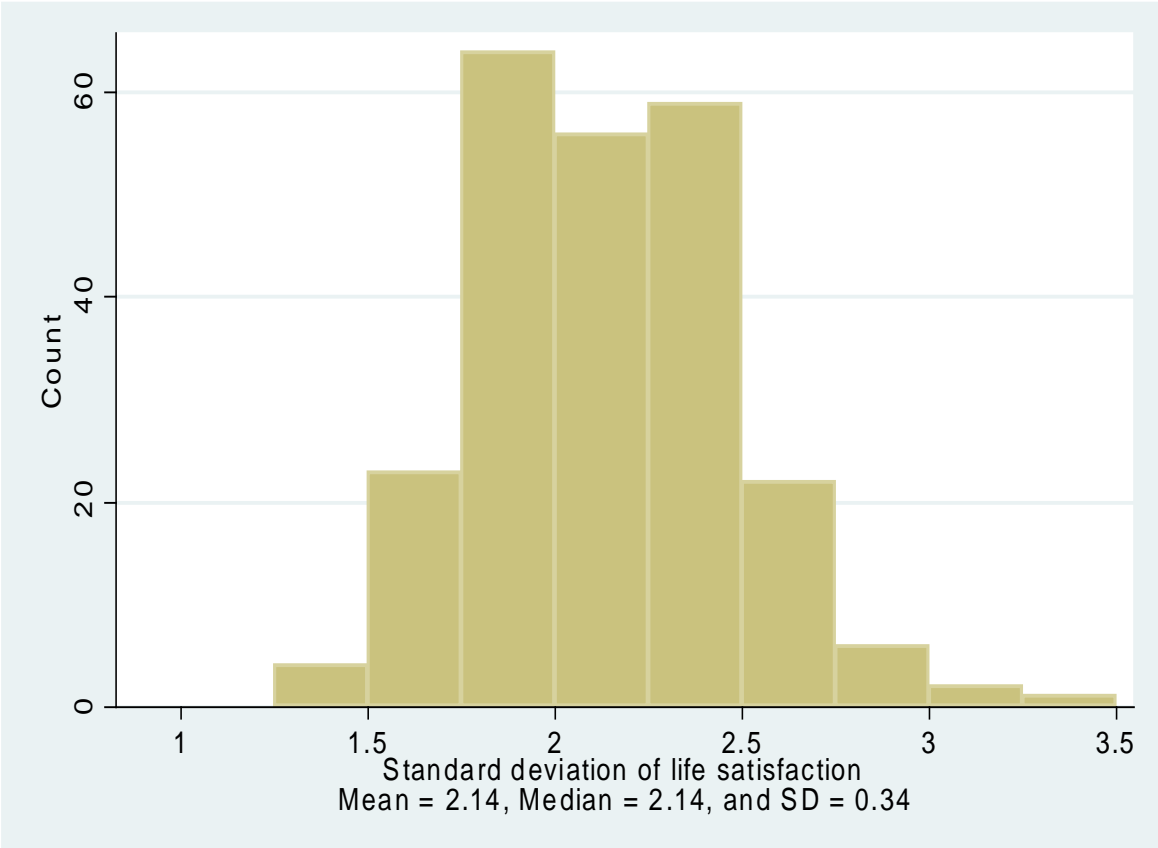


Figure 2a: Scatterplot of standard deviation of life satisfaction and natural log of per capita GDP (in 2000usd)

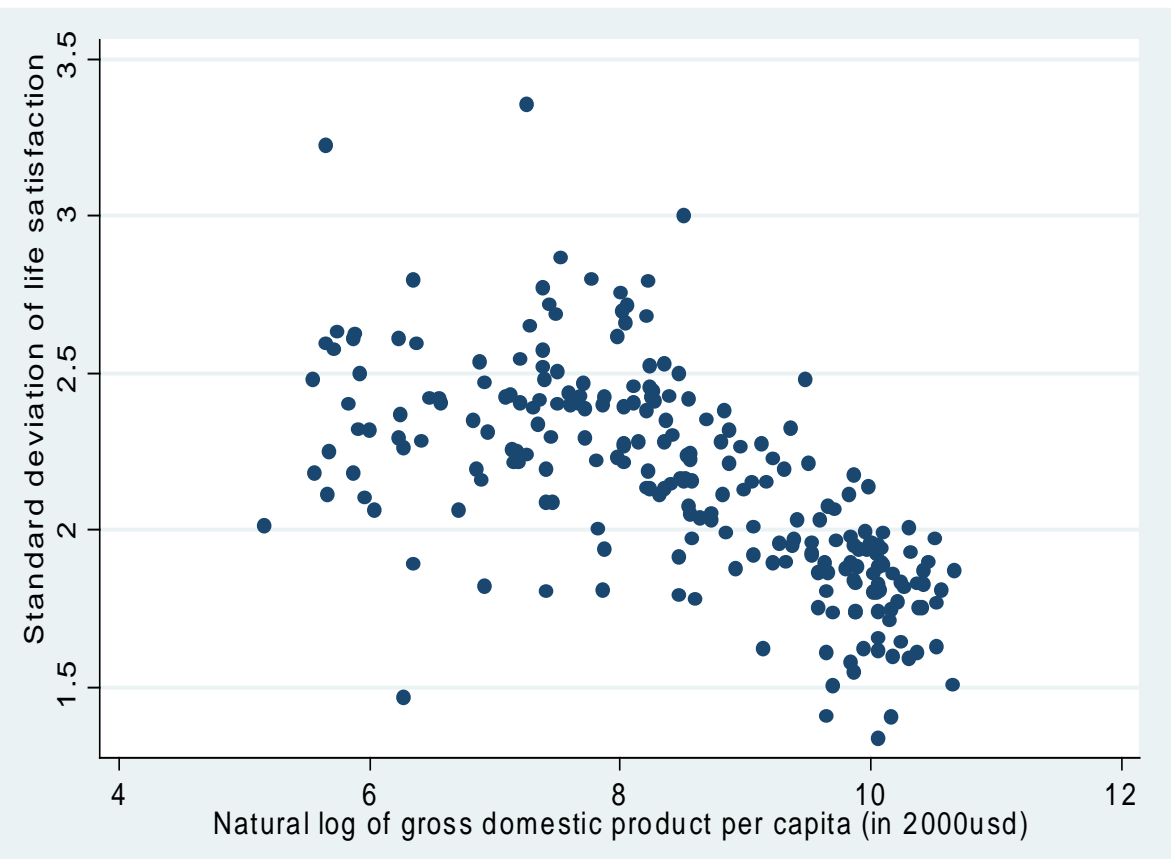

Figure 2b: Scatterplot of standard deviation of life satisfaction and gross domestic product per capita (in 2000usd)

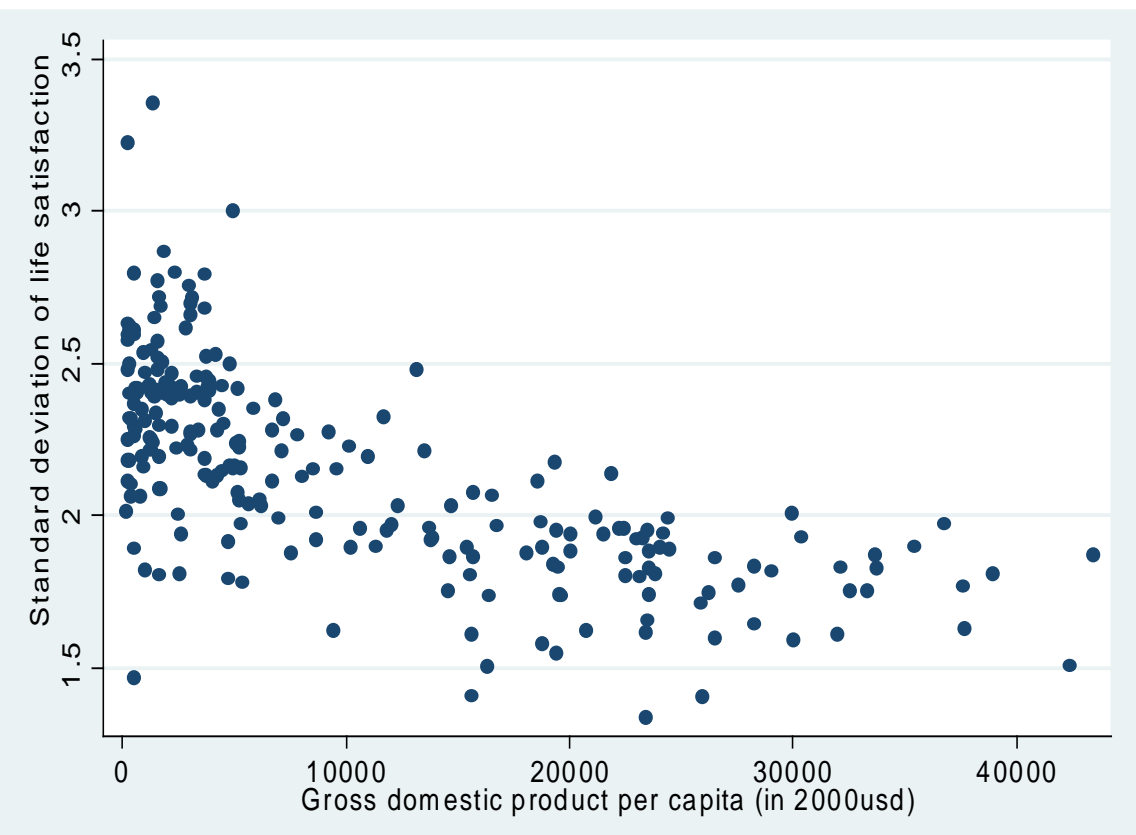


Figure 3: Time-series of U.S. standard deviation of life satisfaction and the natural log of percapita GDP, 1982-2006

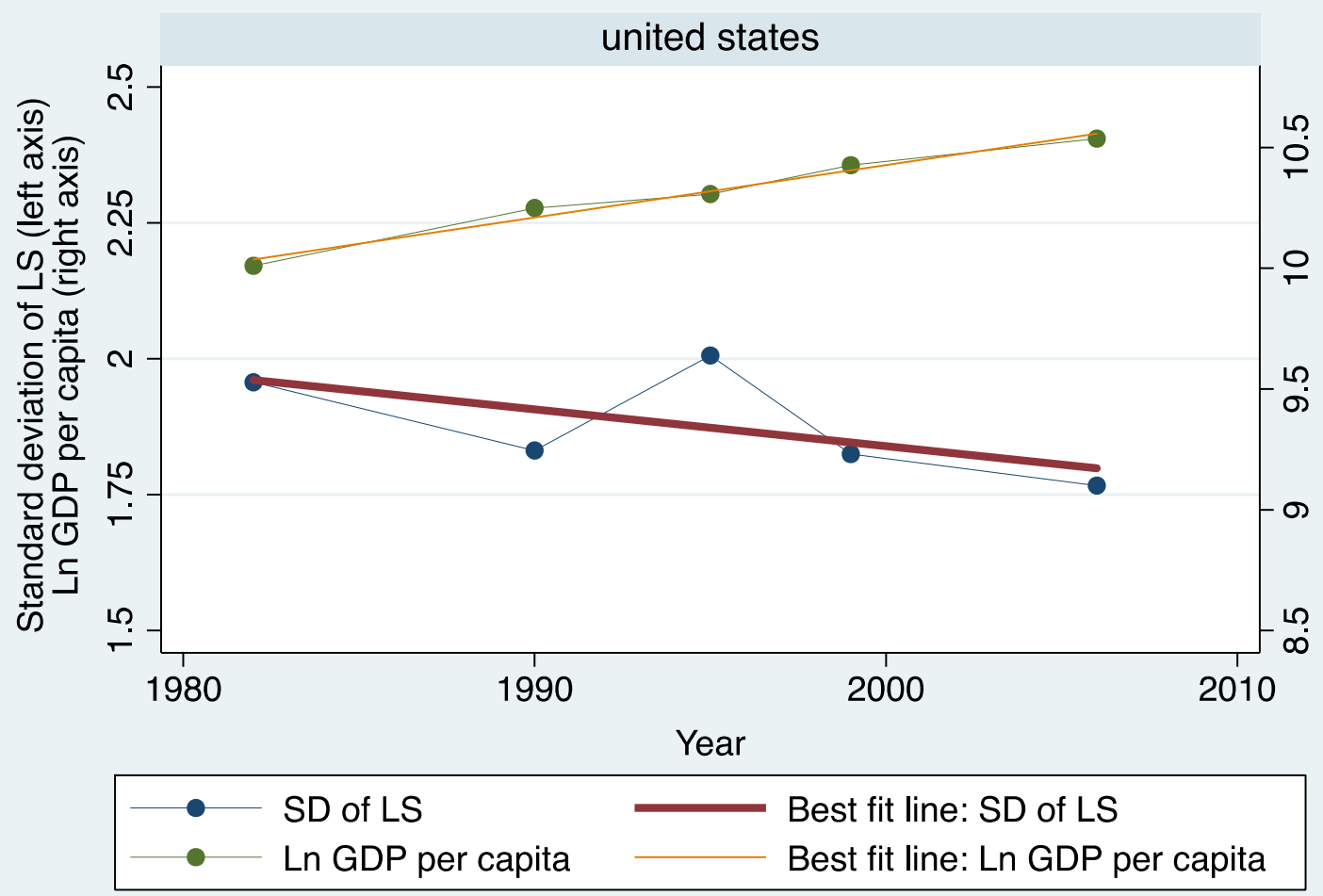

Graphs by country 
Figure 4: Scatterplot of average annual percent change in standard deviation of life satisfaction and average annual percent change in per capita GDP for countries in 5 waves of WVS

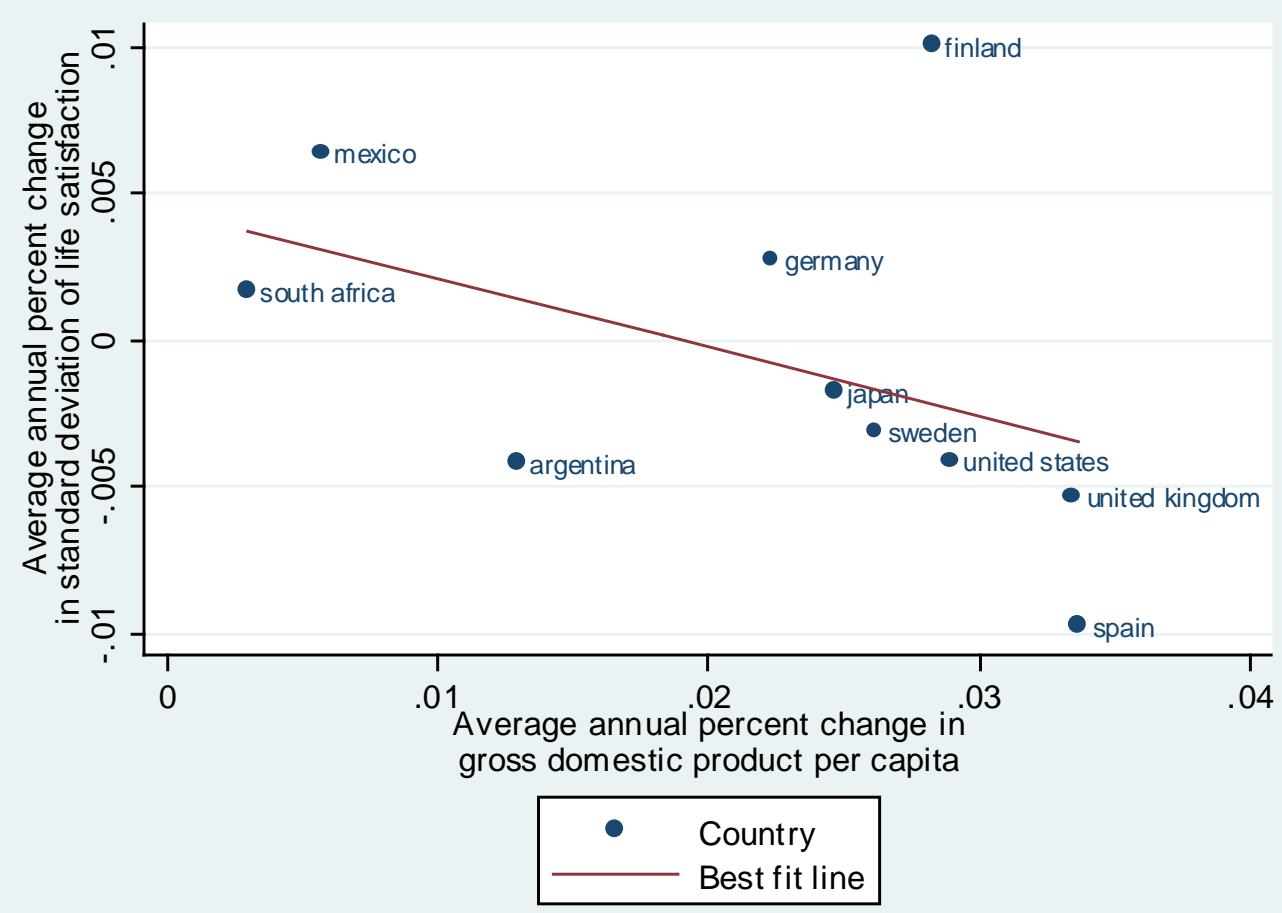


Figure 5: Scatterplot of average annual percent change in standard deviation of life satisfaction and average annual percent change in per capita GDP for countries in at least 4 waves of WVS

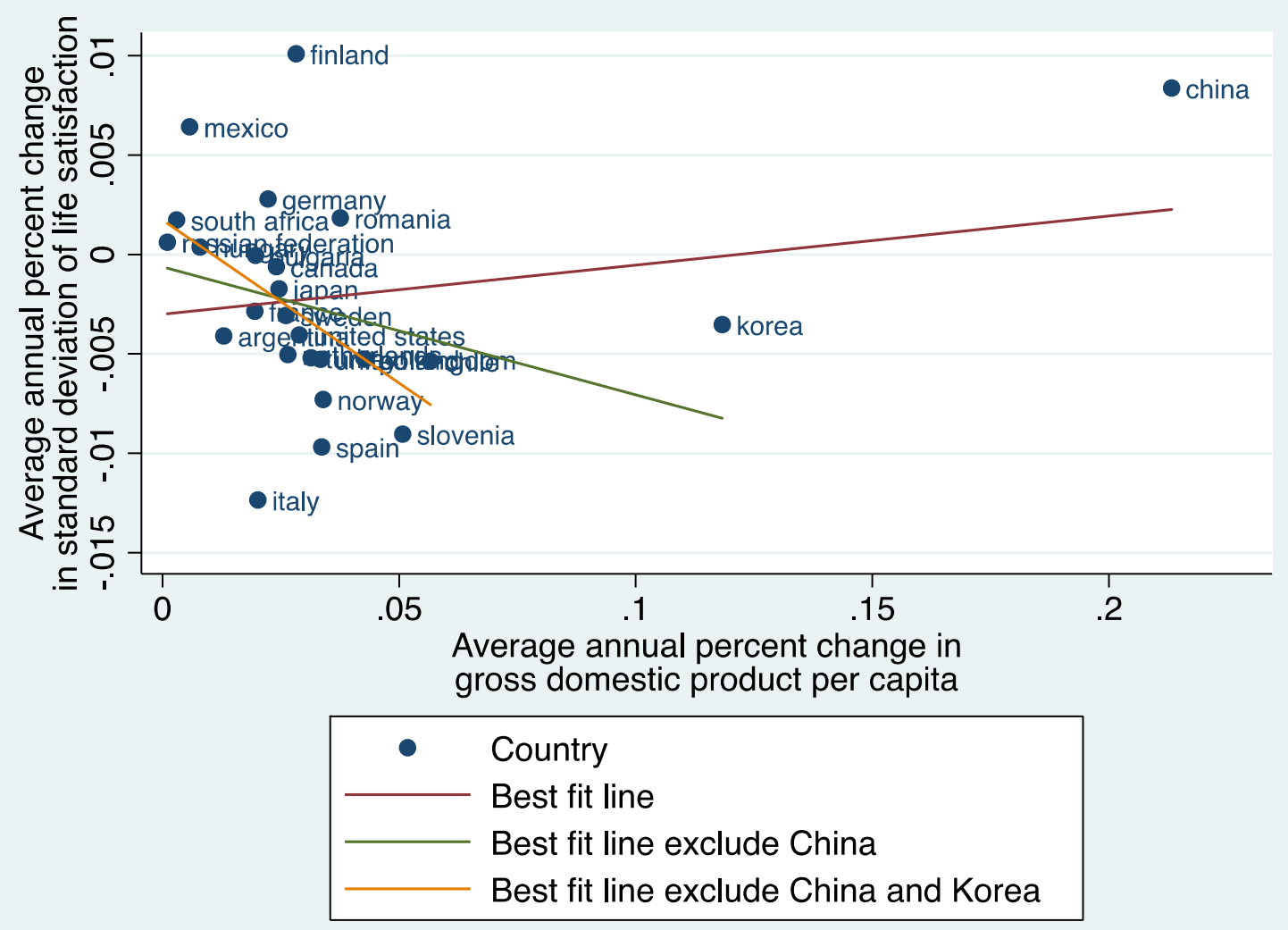




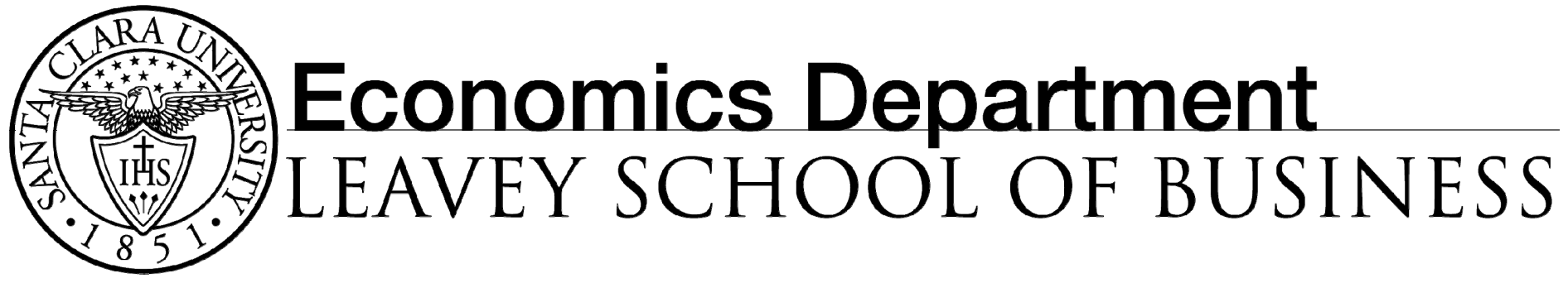

2013

1. Popper, H. Mandilaras, A., Bird, G. 2013. Trilemma stability and international macro economic archetypes. Economics Working Paper 2013-01, Santa Clara University.

2. Field, A., 2013. Schelling, von Neumann, and the Event that didn't occur. Working Paper 2013-02, Santa Clara University.

3. Field, A., 2013. The Savings and Loan Insolvencies in the Shadow of 2007-2023. Working Paper 2013-03, Santa Clara University.

2014

1. Shin, D., Strausz, R. 2014. Delegation and Dynamic Incentives. Working Paper 2014-01, Santa Clara University.

2. Boyd-Swan, C., Herbst, C. Ifcher, J. and Zarghamee, H. 2014. The Earned Income Tax Credit, Mental Health, and Happiness. Working Paper 2014-02, Santa Clara University.

3. Ifcher, John, and Zarghamee, H. 2014. Pricing Competition: A New Laboratory Measure of Gender Differences in the Willingness to Compete. Working Paper 2014-03, Santa Clara University.

4. Ifcher, John, and Zarghamee, H. 2014. Subjective-Well-Being Inequality and Per Capita Income: Evidence from the World Values Surveys. 2014. Working Paper 2014-04, Santa Clara University. 